\title{
Krasicki do Naruszewicza, Mickiewicz do Lelewela, czyli retorycznie o pisaniu historii
}

Violetta Julkowska 


\section{Violetta Julkowska}

\section{Krasicki do Naruszewicza, Mickiewicz do Lelewela, czyli retorycznie o pisaniu historii}

$\mathrm{T}$ eksty literackie, będące przedmiotem niniejszej refleksji, pochodzą z różnych epok historycznych, a mimo to łączą je liczne podobieństwa, dające się zauważyć na pierwszy rzut analitycznego oka ${ }^{1}$. Paradoksalnie łączą je także różnice, o których istnieniu przekonujemy się po wnikliwszej analizie. Oba zatem poddają się łagodnie zabiegowi paraleli, którą traktuję w mojej wypowiedzi jako rodzaj wielopoziomowej strategii retorycznej2.

Zacznijmy więc od wyliczenia punktów, które zbliżają, a zarazem różnicują oba teksty, aby tym samym wskazać elementy tematyczne i zasugerować ich porządek kompozycyjny.

Oto podobieństwa.

Nadawcami obu wierszy są poeci zafascynowani historią i pisarstwem historycznym: Ignacy Krasicki i Adam Mickiewicz. Każdy z utworów ma też podwójnego adresata. Są nimi odpowiednio historycy Adam Naruszewicz i Joachim Lelewel, ale także, z racji przeznaczenia utworów do publicznej prezentacji i druku, określony krąg publiczności czytającej. Oba utwory ze względu na cechy gatunkowe oraz towarzyszący im kontekst zdarzeniowy zaklasyfikować można do twórczości okolicznościowej. W obu zawarty jest wywód metodyczny i historiozoficzny, zgodny z przekonaniami autorów, odnoszący się do dorobku i metodologicznych poglądów historyków-adresatów, a po części również epoki, której dotyczą. Oba wreszcie kreślą idealny wzór historyka swoich czasów.

\footnotetext{
' I. Krasicki, Do księdza Adama Naruszewvicza koadiutora smoleńskiego, w: idem, Satyry i listy, wst. J. T. Pokrzywniak, opr. i koment. Z. Goliński, Wroctaw 1988 (BN I 169), s. 167-176; A. Mickiewicz, Do Joachima Lelewela, w: idem, Wybór poezyj, t. 1, opr. Cz. Zgorzelski, Wroctaw 1974 (BN I 6), s. 79-91.

2 Paralela potraktowana jako retoryczna figura kompozycyjna, a zarazem sposób analizy tekstu, nawiązuje do ulubionej metody historyków XVIII i początku XIX wieku, w tym Lelewela. Por. V. Julkowska, Retorłka w narracji historycznej Joachima Lelewela, Poznań 1998, s. 159-163.
} 
Są i różnice.

Najważniejszą z nich jest czas i okoliczności powstania utworów, bo z nich biorą początek wszelkie przyczyny odmienności, które w tekstach zaistniały. Autorzy i nadawcy, należąc dc różnych mentalnie epok, kierują się w wypowiedziach ideami właściwymi swoim czasor oraz wyłaniającą się z nich wizją świata. To z kolei przyczyniło się do znacznych różnic $\mathrm{w}$ interpretacji wydarzeń historycznych, a ponadto do odmiennego rozumienia misji pisarstwa historycznego. Autorów wierszy dzieli różnica doświadczeń życiowych i twórczych. wynikająca $z$ ich wieku i zajmowanej pozycji. Wreszcie, różny jest ton wypowiedzi, podkreślający charakter relacji osobistych, jakie wiązały nadawców z adresatami utworów.

\section{Odmienne okoliczności, zbliżona sytuacja retoryczna}

Zastosowanie przez obu poetów konwencji właściwej dla wypowiedzi okolicznościowej zainspirowało mnie do bliższego zapoznania się z wydarzeniami towarzyszącymi powstaniu tekstów. Wchodząc w rolę czytelnika dociekliwego i naiwnego zarazem, ciekawa byłam konfrontacji zdarzeń rzeczywistych z sytuacją retoryczną kreowaną przez każdy z utworów. $Z$ fragmentów wypowiedzi, listów i relacji składałam obraz, mający dla mnie wartość kontekstu zdarzeniowego, poddającego się interpretacji.

Oto wiosną 1781 roku Ignacy Krasicki przesłał na ręce króla Stanisława Augusta Poniatowskiego wiersz dedykowany Adamowi Naruszewiczowi, by jeszcze przed jego opublikowaniem został on przedstawiony historykowi. Prezentacja odbyła się, jak wynika z korespondencji króla, na posiedzeniu czwartkowym 3 maja 1781 roku w obecności adresata, przebywającego wówczas w Warszawie z racji pełnienia funkcji sekretarza Rady Nieustającej. W liście datowanym 5 maja Stanisław August informuje Krasickiego o okolicznościach prezentacji jego utworu oraz o wrażeniu, jakie zrobił on na adresacie:

Prędzej odpisać nie chciałem na list WKscej Mci (...), póki przyłączone w nim wiersze na czwartkowym Naszym posiedzeniu przeczytać Mi nie przyszło, ażebym do Mego podziękowania za tak miły prezent pióra WKsMci móg1 zarazem złączyć aplauz pochwał sprawiedliwych calego posiedzenia Naszego, a mianowicie JKsiędza Naruszewicza, jako najosobiściej przezeń obowiązanego. Życzy on sobie, życzy każdy, kto te wiersze WKsMci słyszał, ażeby dziejopisowi polskiego narodu udało się tak dobrze dopełnić powinności wziętego na siebie urzędu, jako WKsMci okryślić je dokładnie i przyjemnie ${ }^{3}$.

Do informacji o charakterze faktograficznym dodajmy komentarz interpretujący te zdarzenia. Wymiana korespondencji, której istotną częścią stał się dedykowany Naruszewiczowi list poetycki Krasickiego, pozostawała w ścisłym związku z rozpoczętym we wrześniu

\footnotetext{
${ }^{3}$ Korespondencja Ignacego Krasickiego, z papierów L. Bernackiego wyd. i opr. Z. Goliński, M. Klimowicz,
} R. Wołoszyński, red. T. Mikulski, t. 2, Wrocław 1958, s. 38 (list nr 298). 
1780 roku drukiem drugiego tomu Historii narodu polskiego Adama Naruszewicza. Towarzyszyła mu zapowiedź rychłej publikacji kolejnych tomów dzieła, co dla czytelników oznaczać mogło, iż w toku przygotowań znajdował się właśnie pierwszy tom Historii, odnoszący się do przedchrześcijańskich dziejów Polski. List Krasickiego można więc zaliczyć do rzędu reakcji oświeconej publiczności czytającej, wywołanej przez pierwsze zwiastuny wielkiego w swym zamierzeniu dzieła historycznego, albo też potraktować jako wypowiedzianą w sposób zawoalowany obawę o to, jaki kształt przybierze naruszewiczowska wizja najdawniejszych dziejów Polski. Krasicki świadomy był trudu wlożonego przez Naruszewicza w trwające latami poszukiwania materiałów źródłowych oraz krytyczne ich opracowywanie. Chodziło jednak o coś znacznie ważniejszego, mianowicie przygotowana przez Naruszewicza narracja miała stać się swoistym testem odwagi cywilnej historyka, a zarazem sprawdzianem praktycznej realizacji idei oświeceniowych na gruncie historiografii. Historyk wspierany protekcją króla przystapił bowiem do rzeczy najtrudniejszej, do stworzenia nowej wizji dziejów ojczystych, przeciwstawiającej się ujęciom tradycyjnym i zarazem czyniącej zadość krytycznym wymogom epoki oświecenia. Naruszewicz już w momencie podjęcia prac nad syntezą zdawał sobie sprawę z kierowanych pod jego adresem oczekiwań, co potwierdza pochodzący z 1775 roku Memoriat:

Nie jest łacno pisać ją [historię] wiernie, dokładnie, porządnie, rozumnie i gładko w tym mianowicie wieku, gdzie przecedzony przez tyle przetaków rozum ludzki, upatrując $w$ dziełach najmniejsze wady i wydziwiając niejako w najwyborniejszym smaku, szuka prawdy bez przysady, pożytku bez pozoru, piękności bez nagany ${ }^{4}$.

W tym kontekście slowa listu poetyckiego i odpowiedź nań ze strony historyka nabierają dramatyczności, wymykając się grzecznościowym formulom. Dodajmy, że życzeniu Naruszewicza stało się zadość - wiersz Krasickiego, znany początkowo w elitarnym kręgu dworskim, doczekal się druku w wydaniu Wierszy X. B. W. z 1784 roku, a następnie w pośmiertnej edycji zbiorowej przygotowanej w latach 1802-1804 przez Franciszka Ksawerego Dmochowskiego.

Przyjrzyjmy się z kolei okolicznościom zaistnienia w świadomości odbiorców wiersza Mickiewicza Do Joachima Lelewela. Autor zaopatrzył go w dopisek, sugerujący bezpośredni związèk z „okolicznością rozpoczęcia kursu historyi powszechnej w Uniwersytecie Wileńskim dnia 9 stycznia 1822 roku" "5. Dopisek ten nie tylko czyni zeń utwór okolicznościowy, związany z dniem inauguracji wykładów Joachima Lelewela, ale także pozostawia silne przeświadczenie, iż właśnie wówczas wiersz został wypowiedziany lub co najmniej wręczony

4 A. Naruszewicz, Memoriat względem pisania historii narodowej, w: Historycy o historii. Od Adama Naruszewicza do Stanistawa Kętrzyńskiego 1775-1918, opr. M. H. Serejski, Warszawa 1963, s. 27-40.

${ }^{5} \mathrm{~W}$ pierwodruku wiersza występuje data 6 stycznia, uważana za pomyłkę wileńskich wydawców (zob. A. Mickiewicz, Wybór poezyj, op. cit.). 
adresatowi. W istocie sprawa przedstawiała się w sposób bardziej złożony, a zachowane re. lacje nie potwierdzają tego powszechnego mniemania. Otóż po kilkuletniej nieobecnośc Lelewela w Wilnie, decyzją władz uniwersyteckich z maja 1821 roku, powierzono mu stanowisko profesora zwyczajnego. Był to powrót z rodzaju tryumfalnych, ponieważ Lelewel wykładający w Wilnie w latach 1815-1818 historię powszechną, dał się poznać jako wybitny znawca przedmiotu i świetny nauczyciel, a zarazem przyjaciel i opiekun swoich studentów Do ich najbliższego grona zaliczał się Adam Mickiewicz. W atmosferze oczekiwania dawn uczniowie historyka planowali szczególny sposób uświetnienia momentu inauguracji. Z icl korespondencji wymienianej między majem a styczniem wynika, że projektowali najpiern subskrypcję, a później wydanie balu na część swojego profesora, lecz ostatecznie żaden z tyck projektów nie został zrealizowany ${ }^{6}$. Szczęśliwym trafem wśród oczekujących znalazł si również Mickiewicz, któremu w roku szkolnym 1821/1822 przyznano roczny urlop, uwalniający go od obowiązku pracy w gimnazjum koweńskim. Dzięki stypendium rządowemı poeta ponownie zamieszkał w Wilnie i z większą swobodą oddawał się pracy literackiej. By: to dla Mickiewicza burzliwy czas romansu z Marylą, bezskutecznych starań u księcia Adama Jerzego Czartoryskiego o posadę na Uniwersytecie Wileńskim, zabiegów wokół wydanic pierwszego tomiku poezji oraz nieustannych infekcji dróg oddechowych. Z korespondencj: wynika, iż właśnie na przełomie grudnia i stycznia 1822 roku poeta poważnie zaniemógł i przez kilkanaście dni nie opuszczał domu z powodu gorączki.

Wróćmy jednak do inauguracji wykładów Lelewela. Wyznaczona początkowo na 7 stycznia, zostala przesunięta na 9 stycznia z powodu braku wolnych miejsc na sali:

Zawczora rozpoczął lekcyje Lelewel. Jak uniwersytet uniwersytetem, nigdy żaden profesor nie miał tylu słuchaczów. Miał rozpocząć w sobotę przeszłą; ale tak się do naznaczonej sali nacisnęlo, tak to potem do drugiej obszerniejszej (...) hurmem biegło i tak ja napełniło, że rektor otoczony licznymi profesorami, nie znalazłszy dla siebie wygodnego miejsca i nie mogąc stłumić szmeru, zapowiedział, że dziś lekcyi nie będzie. W poniedziałek tedy przeznaczono miejsce w sali posiedzeń; od trzeciej prawie (a lekcyja o 5-tej) szli różnego rodzaju słuchacze: akademicy, studenci, palestranci, księża, piszczyki etc. Caluchna sala jak nabita ${ }^{7}$.

Sądzono do niedawna, za sprawą okolicznościowej formy wiersza, ale również informacji zawartej w biografii poety napisanej przez jego syna Wladysława, że Mickiewicz wręczył wiersz Lelewelowi podczas uroczystej inauguracji. Jednak nie potwierdza tego faktu ani powyższa, szczególowa relacja Jana Czeczota, ani też późniejsza korespondencja Lelewela. Natomiast pierwsze sygnały o istnieniu utworu i przekazaniu go Lelewelowi pochodzą

\footnotetext{
' Por. Kronika życia i twórczości Adama Mickiewicza, lata 1789-1824, red. S. Pigon, Warszawa 1957, s. 288, 308, 319.

${ }^{7}$ Archiwum Filomatótv, cz.1: Korespondencja 1815-1823, wyd. J. Czubek, t. 4, Kraków 1913, s. 106-107.
} 
z końca marca. Wtedy to Czeczot w liście do Onufrego Pietraszkiewicza wspomina, że „Adam napisał wiersz piękny do Lelewela”, a z kolei sam Lelewel w liście do rodziny napomyka: „brzęczą lutnie pochwałami, a ja słucham Matki Dobr. i bawełnę w uszy kładę”, co interpretować można jako prawdopodobną aluzję do wiersza Mickiewicza ${ }^{8}$. Ten zaś, krążący początkowo w odpisach, z których młodzież akademicka uczyła się go na pamięć, został ostatecznie wydrukowany dzięki funduszom zebranym wśród braci uczelnianej. Jego egzemplarz na początku kwietnia otrzymał Lelewel, co potwierdził w liście do ojca ${ }^{9}$. Jeszcze w tym samym roku przedruk wiersza ukazał się w warszawskiej „Wandzie” pod zmienionym tytułem Zalety i korzyści historii oraz ponownie w 1828 roku w „Rozmaitościach Warszawskich”.

Z przytoczonych informacji wnioskować można o złożonym charakterze relacji nadawczo-odbiorczych w obrębie komunikacji retorycznej, do której zasad odwołują się oba utwory. To owe zasady odpowiadają za to, iz w naszym mniemaniu (doxa) sytuacja retoryczna, w której uczestniczymy, wydaje się tak rzeczywista. Jednocześnie na podstawie informacji o wydarzeniach skonstatować możemy, że relacja ta ogarniająca nas z poziomu tekstu okazuje się złudzeniem. Oto bowiem zasady sztuki retorycznej w liście poetyckim i oracji powitalnej sprawiają, że sami stając się uczestnikami tej sytuacji, uznajemy autorów wierszy za występujących równocześnie w rolach nadawców oraz wykonawców (silna pokusa zwłaszcza w przypadku oracji skierowanej do Lelewela). Nadal pozostając w kręgu oddziaływania tej sytuacji, utożsamiamy $z$ kolei adresatów tekstów, znanych z imienia, z odbiorcami. A przecież znajomość realiów historycznych, w których teksty powstały i funkcjonowały, podpowiada, że wiersz do Lelewela w rzeczywistości nie został wygłoszony publicznie w dniu inauguracji (prawdopodobnie w ogóle powstał nieco później), natomiast list adresowany do biskupa Naruszewicza w rzeczywistości wysłany został do króla (Krasicki w ogóle nie korespondował z Naruszewiczem) i dopiero tą drogą, publicznie przedstawiony został adresatowi.

Obie sytuacje odkrywają przed nami problem retorycznej fikcji wpisanej w cechy gatunków literackich, która polega na bardzo umownym traktowaniu adresatów i nadawców wypowiedzi. W obu też przypadkach teksty ujawniają podwójnego adresata wypowiedzi, potwierdzając okolicznościowy, a zarazem retoryczny ich charakter. Okazuje się więc, że stała świadomość obecności konwencji to jedna z podstawowych zasad, której respektowania domaga się literatura podczas poddawania jej zabiegom krytycznej lektury historycznej ${ }^{10}$. Pora, aby zdziwienie naiwnego czytelnika, spowodowane niezgodnością faktów, zastąpić krytycznym dystansem towarzyszącym analizie tekstów, chociaż czasami z pozoru naiwna dociekliwość prowadzi do zaskakujących odpowiedzi.

\footnotetext{
8 Por. Kronika życia i twórczości Mickienvicza..., s. 325.

${ }^{9}$ Ibidem, s. 327.

${ }^{10}$ Zob. M. Glowiński, Lektura dzieła a wiedza historyczna, w: Dzieło literackie jako źródto historyczne, red. Z. Stefanowska, J. Slawiński, Warszawa 1978, s. 97.
} 


\section{List poetycki na kształt satyry i list na kształt oracji powitalnej?}

O ile w przypadku utworu Krasickiego jego gatunek literacki określony został przez samego poetę jako list na kształt satyry, o tyle wiersz Mickiewicza pozostawia jego czytelnikom pewien margines dowolności interpretacyjnej. Czy więc utwór Mickiewicza dedykowany Lelewelowi można określić za Juliuszem Kleinerem pseudoklasycystyczną, retoryczné mową wierszowaną, czy może raczej za Wacławem Borowym i Aliną Witkowską doszukiwać się w nim tradycji listu poetyckiego, albo też, jak określa wiersz Maria Janion, poematı historiozoficznego? ${ }^{11}$ A może wiersz ten przygotowany na kształt oracji powitalnej jest pc trosze i listem, i odą zarazem?

Istotne wydaje się tu nie tyle kategoryczne i ścisłe określenie gatunku wypowiedzi, cc raczej przyblizenie ogólnych ram, w których inwencja poetycka Krasickiego i Mickiewicza nabierały każdorazowo właściwych sobie i epoce kształtów, wiernie lub twórczo nawiązując do tradycji.

List poetycki pelnił istotne funkcje społeczne i kulturalne w zyciu literackim epoki oświecenia, co wyraziście potwierdza przykład tekstu Krasickiego, będący jednocześni istotnym składnikiem elitarnej kultury dworskiej. Dał on okazję poecie do błyśnięcia dowcipem i erudycją, lecz w mocy tego tekstu było urabianie opinii publicznej w stosunku dc powstającego właśnie dzieła Naruszewicza oraz zdecydowane zamanifestowanie solidarności $z$ nowymi poglądami na kształt oświeceniowej historiografii. Z racji przeznaczenia utworu do druku jego szersze oddziaływanie było rzeczywiście możliwe, a nie tylko z góry przewidziane w konstrukcji podwójnego adresata listu: odbiorcy prymarnego i publiczności czytającej. Ta cecha gatunkowa listu poetyckiego skutecznie niwelowała jego prywatność, sprawiając, iż osoba adresata traktowana była jako reprezentant szerszej publiczności, a temat listu, choć związany bezpośrednio z działalnością biskupa-historyka, odczytywany jako doniosły społecznie. Przynależący do literatury dydaktycznej list Krasickiego potraktować możemy jako jedną z form satyry, z którą lączy go podobna konstrukcja i forma metryczna, różni zaś filozoficzna postawa podmiotu oraz subtelniejszy i spokojniejszy ton. Analizując konstrukcję tego utworu, spostrzegamy bezpośrednie nawiązanie do pracy Naruszewicza, dalej szerokie przedstawienie własnych rozważań autora listu odnośnie zasad tworzenia historiografii oraz rozumienia prawdy historycznej, a wszystko to w kontekście krytycznych odwołań do przykładów powszechnej i polskiej historiografii wieków wcześniejszych. List ten, operując różnorodnymi strategiami retorycznymi, stara się pełnić funkcję perswazyjną, w mniejszym stopniu wobec przekonanego już adresata, w większym wobec szerokiego kręgu publiczności, nadal czytającej romanse historyczne. Sądzę, że Krasicki jest tu w swym poetyckim

"Por. J. Kleiner, Mickiewicz, t. 1, Lublin 1948, s. 266; W. Borowy, O poezji Mickiewicza, t. 1, Lublin 1958, s. 160; M. Janion, M. Żmigrodzka, Romantyzm i historia, Warszawa 1978, s. 154; A. Witkowska, Historiozoficzna lekcja romantyka. O wierszu „Do Joachima Lelewela”, „Pamiętnik Literacki” 1961, z. 3, s. 31; A. Witkowska, R. Przybylski, Romantyzm, Warszawa 2001, s. 239-240. 
zamierzeniu najbliższy tradycji sięgającej listów Horacego. Pewnej analogii tematycznej i kompozycyjnej doszukać można by się zwłaszcza w Liście do Augusta (epist. II 1: Cum tot sustineas et tanta negotia solus), w którym władcy i społeczeństwu przedstawione zostały nadzieje i obawy poety związane $z$ rozwojem poezji w Rzymie ${ }^{12}$. Zauważmy jeszcze, że list Krasickiego, utrzymany w tonie swobodnej rozmowy, zawiera wyraźnie sygnały stosowności stylu w stosunku do osoby uczonego biskupa Naruszewicza oraz podkreślające powagę sytuacji historycznej, co uwidacznia się w kończącym utwór toposie nawy w niebezpieczeństwie.

Synkretyczny charakter listu dopuszczal obecność w nim także elementów lirycznych, nic więc dziwnego, że poeci i czytelnicy w schyłkowym okresie oświecenia niezbyt ostro odczuwali granicę między listem i odą. Podstawą rozróżnienia obu gatunków nie byly bowiem ani temat, ani też ton, lecz co najwyżej postawa podmiotu mówiącego - w odzie natchnionego i przejętego uniesieniem, w liście zaś zrównoważonego i nastawionego refleksyjnie. Ale to typowo modelowe uproszczenie na lirykę właściwą (oda) i poezję dydaktyczną uwikłaną retorycznie (list) zawodzi w analizie praktyki poetyckiej, skoro twórczość liryczna nasycana byla często treściami dydaktycznymi, a monologi liryczne w odzie konstruowano na modłę retoryczną. Uwagę tę czynię z myślą o wierszu dedykowanym Lelewelowi. Tekst ten, oscylując pomiędzy listem poetyckim, odą i mową, stanowi świadectwo rozluźnienia rygorów gatunkowych na przełomie epok i biegłości poetyckiej zarazem. Chcę tym samym zasugerować pewne podobieństwo konstrukcyjno-sytuacyjne obu analizowanych utworów, które - rzecz biorąc genologicznie - można uznać odpowiednio za list poetycki na kształt satyry i list poetycki na kształt oracji powitalnej, w obu przypadkach z dużą przymieszką konstrukcyjnych elementów retorycznych. Wątpliwość natury formalnej, czy wiersz Mickiewicza spełnia podstawowy warunek sytuacji epistolarnej, jakim jest dystans przestrzenny, rozstrzyga fakt istnienia w poezji klasycznej takiego wariantu listu, w którym oddalenie dzielące piszącego i adresata mogło być pominięte. Jego konstrukcja opierała się na fakcie odwiedzin gościa w domu gospodarza i odpowiadała sytuacyjnie oracji powitalnej. Zważywszy na początkową frazę analizowanego wiersza, zarysowana w nim sytuacja przybycia Lelewela z Korony — skąd pochodzil jego ród i gdzie przebywał przez ostatnie lata — na Litwę bliska jest wspomnianej odmianie listu:

O, długo modłom naszym będący na celu, Znowuż do nas koronny znidziesz LELEWELU! ${ }^{13}$

Jeśli przyjmiemy, że w istocie jest to list poetycki, który przybrał kształt oracji powitalnej, przyjdzie podjąć próbę wyodrębnienia zawartych w nim elementów konstrukcyjno-kompozycyjnych mowy. Pomysłem organizującym temat i kompozycję wystąpienia, dobór toposów i budowę argumentów oraz stosowny styl i ton wypowiedzi jest wyraźnie zarysowana relacja

12 Por. Horacy, List do Augusta, tt. S. Stabryla, w: Rzymska krytyka i teoria literatury. Wybór, opr. S. Stabryla, Wroclaw 1983 (BN II 207), s. 23-36.

${ }^{13}$ A. Mickiewicz, Do Joachima Lelewela, s. 80. 
osobowa mistrz-uczeń, dynamicznie kształtowana przez podmiot. Pojawienie się mistrza będącego celem modłów, staje się okazją do jego pochwały oraz przypomnienia zasłų historyka, które przysporzyły mu sławy i miłości uczniów (w. 1-18), dalej zarysowana zostaj‘ wizja mających nastąpić dopiero spotkań z mistrzem, ale poprzez odwolanie się do analogi sytuacji już przeszłych (w. 19-38) - stąd wrażenie współobecności czasu przeszłego przy. wołanego w teraźniejszym i przyszłego:

Zacznij słynąć cudami dla uczniów natłoku,

Coś je tylekroć sprawit w onegdajszym roku,

Gdy twoim czarodziejskich użyciem sposobów

Greckie i Rzymian cienie ruszaleś spod grobów.

Wstają z martwych, przechodzą na prawdy zwierciadla $(\ldots)^{14}$.

Przypomnienie sztuki ożywiania przeszłości i jawienia jej przed oczyma uczniów prowadzi do konceptu mistrza-czarodzieja i kolejnej pochwały, tym razem profesjonalnych umiejętności historyka w służbie Prawdy (w. 39-56):

Nadarzeń się takowych mnogie żyją świadki,

Przecież ich źródła dociec umie arcyrzadki;

A na podobnej liczbie jeszcze gorzej zbywa,

Co by różnego wątek spajając ogniwa,

Potrafili wybadać za rozsądku wodzą:

Jak się z przyczyny wspólnej różne skutki rodzą $(\ldots)^{15}$.

Bieglość mistrza nie kończy się jednak na doskonale opanowanym warsztacie, któregc świadectwem jest krytyczna analiza źródeł, połączona ze świadomością subiektywnego charakteru wyników prowadzonych badań oraz wszelkich ograniczeń wynikających z uczestnictwa w kulturze i zanurzenia w tradycji (w. 57-78). Przezwyciężenie tych ograniczeń widzi uczeń w sile natchnienia swego mistrza, w jego geniuszu, który cechuje oryginalnego myśliciela (w. 87-100):

Tylko sam, komu rzadkim nadało się cudem

Złączyć natchnienie boskie z ziemianina trudem (...)

$\mathrm{Na}$ świętym dziejopisa jaśniejąc urzędzie,

Wskazujesz nam, co było, co jest i co będzie ${ }^{16}$.

Naturalną koleją rzeczy dochodzi także do swoistego popisu biegłości w opanowaniu sztuki ujmowania dziejów w wykonaniu ucznia natchnionego wszechogarniającą ideą, który przez dłuższą chwilę skupia na sobie całą uwagę mistrza i audytorium (w. 101-210). Wreszcie

${ }^{14}$ Ibidem, s. 81, w. 21-24.

15 Ibidem, s. 82, w. 43-47.

${ }^{16}$ Ibidem, s. 84, w. 89-90, 99-100. 
powrót w toposie skromności do sytuacji wyjściowej - końcowa pochwała niedoścignionego w swej bieglości ogarniania i przedstawiania dziejów historyka (w. 211-228).

Wyraźnie wyodrębniają się więc: uroczysty wstęp, w którym odczucia podmiotu wypowiadane są w imieniu całej społeczności akademickiej (w. 1-18), oraz zakończenie, które po odwołaniu się do toposu skromności zamyka symboliczna scena, nawiązująca do tradycji wręczenia lauru akademickiego, ale tu potraktowana metaforycznie w odniesieniu do uczniów (w. 211-228).

Wiersz Do Joachima Lelewela jest romantyczną pochwałą geniuszu historyka, ułożoną $\mathrm{w}$ stylu retorycznym, co jest paradoksem, podobnie jak romantyczny manifest zawarty w Odzie do intodości.

Pozostaje jeszcze do rozważenia zasiana wcześniej wątpliwość dotycząca pokrewieństwa utworu Mickiewicza z odą. W polskich poetykach, wydawanych pod koniec XVIII wieku, pojawiło się stanowisko modyfikujące tradycyjne postrzeganie ody, mianowicie wskazujące na związek ody, przynależącej do poezji lirycznej, z wymową. Zwłaszcza Filip Neriusz Golański przypisywał odzie zdolność do wyrażania gwałtownych poruszeń serca, podziwu, radości, wdzięczności i uwielbienia oraz nadzwyczajnej mocy, którą porównać można do siły „bystrej wody zalewów lub ognia z wiatrem wybuchającego”. Przyzwolenie poetyckiego uniesienia jako domeny ody wystąpiło jeszcze wyraźniej u estetyków okresu postanisławowskiego. Ludwik Osiński i Euzebiusz Słowacki zgodni byli co do tego, że podstawowym wyznacznikiem ody jest entuzjazm, dzięki któremu utwór powinien porywać i zachwycać słuchaczy w nie mniejszym stopniu, niż przekonywać. Entuzjazm i natchnienie, wielkość i moc zawartych w niej myśli motywować miały jej wysoki ton, ale jednocześnie dopuszczać pozorną chaotyczność obrazów poetyckich.

Czytając Mickiewicza, mam wrażenie, że jego wiersz, choć nie opatrzony etykietą gatunkową, wchłonął różnorodne elementy emocjonalnego przekazu, czerpiąc z oświeceniowej tradycji ody panegirycznej oraz ody filozoficznej. Są tu więc obecne charakterystyczne wysokie tony pochwalne skierowane do osoby wybitnego historyka, mistrza i przyjaciela, podkreślające jego zasługi dla rozwoju nauki historycznej i zarazem wychowawczy wpływ na grono uczniów. Są również dość autorytatywnie przekazane prawdy filozoficzne na temat dziejów ludzkości, idące w kierunku zaangażowania i perswazji emocjonalnej, charakterystycznej w odach romantycznych.

Ale być może tym, co najbardziej zbliża do siebie oba tak różne teksty, jest właśnie stała obecność retoryki, zaznaczająca się na poziomie kompozycji, w konstrukcji monologu wypowiadanego przez podmiot, w perswazyjnym tonie tych wypowiedzi, wreszcie w stosowności stylu odnośnie osoby historyka i tematu, jakim jest sztuka pisania historii. 


\section{Literacki portret historyka-mistrza-mówcy-poety}

Pomimo doniosłej kulturowo i społecznie tematyki utworów Krasickiego i Mickiewicza uderza w nich bardzo osobisty ton, który sprawia, że w tekstach tych, obok bezpośrednick adresatów, niezwykle wyraźnie zarysowują się oba podmioty wypowiedzi, utożsamiani $z$ autorami-nadawcami tekstów.

Adam Naruszewicz w wierszu Krasickiego jawi się jako doświadczony i zaprawiony w poszukiwaniach źródlowych historyk, od lat pracujący nad stworzeniem nowego, synte. tycznego ujęcia dziejów. Podobnie jak Ignacy Krasicki, jest człowiekiem sprawującym wyso. kie godności w hierarchii kościelnej, w całości zawdzięczającym swą pozycję królowi. Rów. nież droga wiodąca obu biskupów do historii nie była jak na owe czasy ani wyjątkowa, an niezwykła, bowiem wielu historyków rozpoczynało swą karierę pisarską od teologii, filologi klasycznej i poezji. Znajomość sztuki pisania stanowiła więc w sposób niejako naturalny częśi profesjonalnych kompetencji historyka, wzmocnionych znajomością ogólnych zasad sztuk pisania rodem $z$ retoryki. Inaczej sprawy miały się $z$ reprezentowaną przez obu historykón koncepcją dziejów. Ta zależna była od podzielanej przez nich wizji świata, a więc zarazen systemu wartości i ocen, a ponadto od rozwoju metod i stanu badań historycznych w danyr okresie oraz reprezentowanej przez nich indywidualnej świadomości epistemologicznej.

Joachim Lelewel w wierszu Mickiewicza zaznacza swą obecność po czterykroć powtórzoną retoryczną aklamacją, wezwaniem, które na zmianę stają się bądź to twierdzeniem, bądź to pytaniem retorycznym. Wokól trzech pierwszych zbudowany został, wypelniający połow६̨ utworu, pean na cześć historyka-mistrza-mówcy-poety, prawdziwie romantycznego, bc żyjącego i pracującego w sposób angażujący pełnię jego człowieczeństwa. Człowieka rozumiejącego misję historyka jako polegającą na głoszeniu prawd żywych, dzięki sztuce wymowy: perfekcyjnej metodzie krytyki źródel, samoświadomości metodologiczno-filozoficznej i boskiemu natchnieniu. Z kolei czwarte przywołanie nazwiska profesora, odwolujące się do jego autorytetu i jednocześnie wyrażające pełną pokory postawę wobec jego wiedzy i geniuszu, zamyka orację, stawiając u boku mistrza jego ucznia. Zamyka to ostatnie zawolanie druga część wiersza, wypełnioną panoramicznym obrazem dziejów powszechnych. Zanim przyjrzymy się historiozoficznej wymowie tego niezwykłego obrazu, warto zauważyć, że powstal on w wyniku natchnienia, które za sprawą mistrza udzieliło się i jego uczniowi.

Mickiewicz zdaje się podzielać świadomość swego mistrza, że historia, będąc autorefleksja kultury, sama jest jej wytworem. Na ten trudny do przezwyciężenia subiektywizm wszelkich badań i narracji historycznych obaj widzą jedną radę - ufilozoficznienie historii. Tylko spoglądanie na historię przez pryzmat wielkich idei poruszających jej bieg daje ludziom namiastkę boskiego obiektywizmu, bo daje perspektywę ogarniającą dzięki owym ideom ogromną przestrzeń i czas. Jednocześnie jest to zabieg nadający ludzki wymiar i sens historii. I bodaj jest to najważniejsza lekcja znakomicie przyswojona przez poetę, wystawiająca mu w oczach audytorium opinię genialnego ucznia. 
W kontekście rozważań na temat konstrukcji podmiotów mówiących warto przypomnieć, iż w obu przypadkach osoby adresatów stają się punktem odniesienia do zaprezentowania szerszej publiczności określonego modelu postępowania historyka oraz tworzenia historiografii. Wobec szerokiego audytorium odbiorców podmiot w obu utworach przyjął postawę niezależnego mentora, arbitralnie formułującego bądź tylko przywołującego zapoznane wcześniej sądy i racje. Podmiot wypowiadającyje w liście poetyckim Krasickiego czyni to $z$ pełnym przekonaniem, w przeświadczeniu racjonalnie dających się wyodrębnić reguł sztuki. Podmiot w wierszu Mickiewicza, choć świadomy swej wiedzy i umiejętności, powołuje się na autorytet mistrza.

\section{Historyzm oświeceniowy w ujęciu Krasickiego}

Krasicki przedstawił w liście poetyckim własną wizję historiografii, wymagającej gruntownego przewartościowania dotychczasowych sądów i ocen o czasach minionych. List był próbą ogarnięcia całości problematyki związanej z rozumieniem historii i roli historyka, utrzymaną w duchu oświeceniowym. Jednakże w części dotyczącej sposobu konstruowania narracji historycznej Krasicki dość wiernie nawiązał do tradycji historiograficznej czasów starożytnych. Współcześni badacze literatury wskazują bowiem, że źródlem szczególowych uwag Krasickiego na temat konstrukcji i stylu narracji jest rozprawa Lukiana z Samosaty Jak historię pisać nale ży, pochodząca z II wieku, przetlumaczona we fragmentach przez poetę:

Niełatwe to jest dzieło dzieje ludzkie głosić, Poniżać, gdzie należy, gdzie trzeba, wynosić, Dać poznać, jak się rzeczy na świecie kojarzą, Środek między podchlebstwem trzymać a potwarzą,

Czerpać rzeczy istotę w ich właściwym źródle,

Obwieszczać bez przysady, prosto, a nie podle, Co godne wiadomości, to tylko okréślać $(\ldots)^{17}$.

Sparafrazowane wskazania starożytnego znawcy retoryki przedstawiają historyka nie tylko jako dającego w swej relacji historycznej proste świadectwo wydarzeń, lecz przede wszystkim jako obdarzonego głębokim namysłem konstruktora obrazu przeszłości. Do jego rozlicznych kompetencji miała należeć decyzja o tym, które $z$ wydarzeń przekaże on potomności jako istotne oraz w jaki sposób je oceni, czyli swoista selekcja i hierarchizacja materiału zdarzeniowego, polączona z kompetencjąjęzykowo-stylistyczną. Ta ostatnia wyrażała się w sugestii zastosowania w dziele historycznym stylu średniego, będącego miarą ozdobności słownictwa i struktur składniowo-prozodyjnych. Historyk jako twórca narracji występować mógł również w roli arbitra, wskazując, ,jak się rzeczy na świecie kojarzą”, czyli ustalając rodzaj

${ }^{17}$ I. Krasicki, Do księdza Adama Naruszetvicza..., s. 168, w. 11-17. 
związków i relacji między wydarzeniami. W konsekwencji byla to zapowiedź pracy konstruk cyjnej na poziomie kompozycyjnym narracji historycznej. Powyższy sposób interpretacji listı Krasickiego, we fragmentach odnoszących się do wykonywanej przez historyka pracy kon cepcyjno-badawczej, świadczyć może o wysokim poziomie świadomości metodologiczne poety bądź o celowym nawiązaniu do powszechnie respektowanej, wielowiekowej tradycj pisania historii, wywodzącej się ze starożytnej retoryki. Tworzenie tekstów o charakterzı historycznym obywało się bowiem przez wiele stuleci bez konieczności formułowani odrębnych wskazań teoretycznych. Klasyczna teoria retoryczna oraz swoisty ethos historyka pojmowany jako obowiązek przedstawiania prawdy, zlożyly się na pragmatyczny mode historiografii obowiązujący od czasów Herodota do XVI stulecia. Dopiero humanistyczn teoria historiografii, formułująca ścisłe normy kompozycyjne i estetyczne, stworzyła specy ficzny kanon dzieła historycznego, mającego imitować styl historyków starożytnych. Rozwó badań krytycznych zapoczątkowany w XVII wieku zmienial stopniowo sztukę pisania histo. rii, traktowaną dotąd jako umiejętność literacka, w dyscyplinę naukową opartą na systema. tycznie doskonalonym warsztacie badawczym. Nie oznaczało to jednak natychmiastowegr zerwania tradycyjnych związków retoryki z historią, która nadal wywierała wpływ na ksztal wykładu dziejów. Pisarze oświeceniowi, a wśród nich Stanisław Konarski, reprezentując nurt retoryki systemowej, podjęli walkę $z$ dominującym w XVII wieku elokucyjnym nurten retoryki. Tak więc cytowaną wypowiedź Krasickiego uznać można za powrót do dawnycl źródeł kunsztu, nieskażonych tendencją panegiryczną czy też manierą stylistyczną. Uwag Krasickiego na temat stylu narracji pozostają w zgodzie z ogólną tendencją epoki, zmierzając: do wypracowania stylu prozy historycznej. Cechować miały go prostota, jasność, umiarko. wanie w stosowaniu środków retorycznych oraz zwięzłość wypowiedzi, stosownie dobrant do materii historycznej.

W tekście listu poetyckiego obok wskazówek, będących częścią tego tradycyjnego modelu odnajdziemy także obszerną refleksję na temat prawdy w narracji historycznej, która zdaniem poety stanowi istotę pracy historiografa. W wypowiedzi Krasickiego pobrzmiewają wyraźnє wpływy idei oświeceniowych. Znaczną część rozważań wypełnil problem eliminacji jawnej fikcj: z narracji historycznej, zwłaszcza w odniesieniu do najdawniejszych dziejów Polski.

Nasze ojcy podściwe dobre mieli serce,

Nie chcieli nawet bajek trzymać w poniewierce,

Stąd te jeden za drugim owczym bieżąc pędem,

Skoro zełgał najpierwszy, wszyscy łgali rzędem.

$\mathrm{Z}$ ich laski poza morze granic naszych meta,

$\mathrm{Z}$ ich łaski ród Magoga, Tubala, Jafeta,

A tak dobrze ułożon, iż za pilnym składem

Wiemy, kto naszym przodkiem, dziadem, prapradziadem ${ }^{18}$.

${ }^{18}$ Ibidem, s. 169, w. 23-30. 
Za pełnymi ironii słowami Krasickiego kryje się postulat wnikliwej krytyki źródel historycznych, pozwalającej na ustalenie autentyczności i wiarygodności informacji pochodzących z różnych przekazów. Do czasów saskich podstawowy zrąb podań o przedhistorycznych dziejach Polski, pochodzący z kronik Galla Anonima i Wincentego Kadlubka, przekazywany był w wersjach wzbogaconych o szczegóły, a jego wiarygodność nie była zasadniczo kwestionowana. Dopiero ukształtowany w czasach oświecenia nowy pogląd na rzeczywistość, w tym również rzeczywistość przeszłą, przyczynił się do stopniowego eliminowania z narracji historycznej elementów jawnie fikcyjnych. Należały do nich baśniowe i mitologiczne relacje o początkach dynastii, państw i narodów, barwne historie postaci legendarnych, których istnienie i działalność nie posiadała poświadczenia źródłowego. Pojawiły się więc, obecne także w wypowiedzi Krasickiego, postulaty, aby z narracji historycznej odrzucano nie tylko elementy, które w konfrontacji ze źródłami okazywały się fikcją, ale też i takie, których nie dało się pogodzić ze zracjonalizowanym obrazem świata, kształtowanym przez filozofię oświecenia. Zdaniem Krasickiego dziejopis w imię prawdy historycznej powinien odrzucić wszelkie legendy i fantastyczne opowieści, których właściwym miejscem jest literatura, a nie historia.

Dość ciemna zawżdy przeszłość, po cóż ją kunszt ciemni?

Na co pisać, jeśli się zmyślać zda przyjemniéj.

Wielkie pole romansów i te kreślić sztuka,

Niech miejsce naszej Wandy zajmie Banialuka (... $)^{19}$.

Stanowisko Krasickiego prezentowane w liście oznacza zatem zracjonalizowane podejście do zagadnienia prawdy historycznej i konstrukcji narracji historycznej, zgodnie z wymogami oświeceniowego historyzmu. W tym przekonaniu utwierdza nas również zapowiedź definitywnego rozdzielenia historii świętej i świeckiej, a więc wyłączenia dziejów biblijnych z narracji historycznej, będąca efektem postępującej laicyzacji myślenia ${ }^{20}$.

\section{Historyzm romantyczny w ujęciu Mickiewicza}

Wiersz Mickiewicza adresowany do jego uniwersyteckiego mistrza i przyjaciela Lelewela traktowany jest przez historyków literatury jako świadectwo historiozoficznych poglądów poety, przy czym ich rozważaniom towarzyszy poważna różnica zdań co do źródeł inspiracji filozoficznych poety ${ }^{21}$. Z kolei zdaniem Henryka Łowmiańskiego, który jako jedyny bodaj

\footnotetext{
${ }^{19}$ Ibidem, s. 172, w. 45-48.

${ }_{20}$ Por. J. Topolski, Od Achillesa do Beatrice de Planissolles. Zarys historii historiografii, Warszawa 1998, s. 69-72; A. F. Grabski, Zarys historii historiografii polskiej, Poznań 2000, s. 72-77.

${ }_{21}$ Por. A. Witkowska, Historiozoficzna lekcja romantyka..., s. 23-49; S. Pigon, Historiozofia mlodego Mickiewicza na tle literatury wieku Oświecenia, w: idem, $Z$ epoki Mickiewicza. Studia $i$ szkice, Lwów 1922; R. Pilat, Wiersz A. Mickiewicza do J. Lelewela, „Pamiętnik Literacki” 1887, s. 78-94; H. Życzyński, Adant Mickiewicz. I. Mtodośc, Lublin 1936.
} 
z historyków wypowiedzial się w tej kwestii, wiersz jest wymownym świadectwem oddzialywania Lelewela na młodzież akademicką oraz ustalenia się jej światopoglądu jako skutkı tego oddziaływania:

Nawiązywanie do współczesnej literatury historiozoficznej wydaje się celowe tylko przy uwzględnieniu Lelewela jako ogniwa pośredniego, gdyż jego oczami oglądal Mickiewicz w tym czasie proces dziejowy ${ }^{22}$.

Z prowadzonej przez wiele lat dyskusji wynika coraz jaśniej, iż młody Mickiewicz swe poetyckiej interpretacji dziejów nadał charakter autorski, choć nie ukrywał fascynacji poglądami filozoficznymi Lelewela oraz w ślad za nim twórców dwóch odrębnych nurtów oświeceniowej filozofii: $z$ jednej strony reprezentantów filozofii prawa natury, dla których podstawą społecznego wymiaru dziejów byla niezmienna natura ludzka, oraz z drugiej strony przedstawicieli nurtu oświeceniowego historyzmu, zwłaszcza Herdera jako prekursora historiozofii romantycznej. Świadczy to nie tyle o eklektyzmie filozoficznym poety, co raczej o głębokich korzeniach romantycznej filozofii historii. Ponadto jest to pośrednio świadectwo tradycji oświeceniowej, reprezentowanej na początku XIX wieku przez uniwersyte1 w Wilnie, którego Mickiewicz byl wychowankiem, zbuntowanym co prawda za sprawa Lelewela, ale przecież jednak ponad miarę pilnym i zdolnym uczniem swych z ducha oświeceniowych nauczycieli.

W wierszu Mickiewicza odnaleźć można więc idee i poglądy oświeceniowe, ale właściwa ich interpretacja, jak ponad wszelką wątpliwość wykazała Alina Witkowska, związana jesı z wcześniejszym ich przyporządkowaniem określonemu nurtowi filozofii dziejów ${ }^{23}$. Przykładowo - z idei rozwoju historycznego, polegającej na walce dwu przeciwieństw: wolności i despotyzmu, Mickiewicz uczynił istotny element konceptualizacji przedstawionej przez siebie wizji dziejów powszechnych, co pozwoliło nadać im ujęcie syntetyczne. Idea ta była co prawda eksponowana już przez filozofów oświeceniowych spod znaku praw natury, ale dopiero zwolennicy oświeceniowego historyzmu odebrali jej wymowę moralną i spoleczną, nadając $w$ zamian zabarwienie ściśle polityczne. Już ten przykład świadczy o złożonym, aczkolwiek dynamicznym charakterze powiązań filozoficznych, jakie poeta-romantyk przeją 1 wraz z dorobkiem kulturowym epoki oświecenia drogą akademickich wykładów Lelewela oraz samodzielnych lektur. Tak więc, choć syntetyczne ujęcie historii powszechnej Mickiewicza nawiązuje swą wierszowaną formą do tradycji poematów historiozoficznych, to jednak analiza sposobu ujęcia treści historycznych przeczy temu pozornemu podobieństwu. Bowiem poprzez zdecydowane odrzucenie utartych schematów ujmowania historii na rzecz określonej idei rozwoju historycznego, która porządkuje na poziomie inwencyjnym i dyspozycyjnym przekaz treści historycznych, Mickiewicz opowiada się już świadomie po stronie

${ }^{22}$ H. Łowmiański, $Z$ działalności dydaktycznej Joachima Lelewela w Uniwersytecie Wileńskim, „Neodidagmata”, nr VII, Poznań 1975, s. 42.

${ }_{23}$ Por. A. Witkowska, Historiozoficzna lekcja romantyka..., s. 27. 
historyzmu, nie zaś po stronie statycznie i moralistycznie ujmowanych dziejów, przypominających swym kształtem romans historyczny. Jest to prawdopodobnie skutek dobrze zapamiętanej lekcji danej studentom przez Lelewela, ponieważ ten rodzaj pisarstwa pseudohistorycznego, stawiany na równi z fikcją literacką, analizowany był szczegółowo we wstępie do wykładów $z$ historii powszechnej ${ }^{24}$. Lelewel podkreślał zwłaszcza odmienność osiemnastowiecznej historiografii francuskiej, udramatyzowanej i „uromansowanej”, w zestawieniu z historiografią angielską, wskazując tym samym na leżące u podstaw tej odmienności różnice filozoficzne:

Dana wypadkom wygłada dorywczo zadziwia ciekawość, obleczona historia w obraz romansu, prawda tyle zachowana, ile założonemu urojeniu, ile ślepej dowolności sprzyja, wreszcie podnoszone cnoty, czernione postępki od rzutu dowcipu i ochoty chętniej ze złej strony patrząc (...) lub niekiedy do zamierzonego celu dążą 25 .

Mickiewicz podążył tropem wykładów Lelewela, a omijając rafę utopijnie ujmowanego przez większość historyków początku dziejów ludzkich, dał dowód sceptycyzmu wobec dociekań pozbawionych podstaw naukowych. W dynamicznym obrazie starożytnej Grecji i Rzymu podzielił sympatię polityczną Lelewela dla będącej uosobieniem wolności i piękna Grecji oraz antypatię dla despotycznego i barbarzyńskiego Rzymu. Jednak kierowany względami artystycznymi dokonał dość dowolnie licznych zabiegów selekcji wydarzeń, inaczej też niż Lelewel wiązał je w ciągi przyczynowo-skutkowe. Uzyskany w ten sposób efekt kondensacji obrazów nadał wizji historycznej autorski charakter, zblizając ją raczej do praw licencji poetyckiej aniżeli do wymogów sumienności relacji stosownej u historyka.

W sposobie oceny średniowiecza Mickiewicz podobnie jak Lelewel przeciwstawił się opinii oświeconych, widząc w kulturze Europy Północnej stale źródło żywotności wspólczesnej mu kultury europejskiej. Jednak i tutaj wizja poetycka góruje nad rzetelnością $\mathrm{w}$ przedstawianiu faktów, a przemilczenia niewybaczalne $\mathbf{u}$ historyka są dla poety źródłem mocy w oddziaływaniu jego obrazów. Próbą samodzielności w ujmowaniu dziejów były dla poety ostatnie wersy, w syntetycznym ujęciu prowadzące do czasów współczesnych, bo aż do rewolucji francuskiej i epoki napoleońskiej. Wybiegając w przyszłość, poeta poddaje próbie siłę swego geniuszu i natchnienia, przewiduje komplikacje polityczne po śmierci Napoleona, nie wierząc, iż upadek rewolucji przyniósł kres czasom wolności. Tym spojrzeniem w przyszłość, uzasadnionym z punktu widzenia historiozofii romantycznej, pozostaje w zgodzie $z$ nauką mistrza Lelewela.

2ł J. Lelewel, Wstęp do historii powszechnej (wykłady odtworzone z notat studentów), w: idem, Dziela, opr. N. Assorodobraj, t. 2, cz.1, Warszawa 1964, s. 273.

${ }^{25}$ J. Lelewel, Dzieje historii, jej badań i sztuki, w: op. cit., t. 2, cz. 2, s. 824-825. 


\section{Zamiast zakończenia}

Konstrukcja paraleli jako figury kompozycyjnej pozwoliła ukazać mi oba teksty, zwracająı uwagę na ich różnice i trudniejsze do uchwycenia podobieństwa. Droga prowadziła doś żmudnie od próby zarysowania retorycznej sytuacji wygloszenia tekstu, będącej swoistyr komentarzem źródlowym do obu wierszy, aż po wielowątkową analizę utworów wraz z ick kontekstami krytyczno-literackim i filozoficzno-metodologicznym.

Dla historyka poszukującego informacji w dziele literackim o charakterze okolicznościo. wym, a więc bliskim sferze zdarzeniowej, jest to doświadczenie uczące pokory. Uświadami: bowiem, że autorzy tekstów historycznych i literackich mają na uwadze identyczne punkt, odniesienia: człowieka i świat. W akcie komunikacji ze swoimi czytelnikami zarówno jedni jak i drudzy odwołują się do tego samego zbioru przeżyć i doświadczeń ludzkich, a światy które budują, wzajemnie się uzupełniają i domykaja. To zaś, co ich różni, to specyficznt sposoby, w jaki owe światy powstają. 